\title{
The chemical and biological response of two remote mountain lakes in the Southern Central Alps (Italy) to twenty years of changing physical and chemical climate
}

\author{
Aldo MARCHETTO*, Rosario MOSELLO, Michela ROGORA, Marina MANCA, Angela BOGGERO, \\ Giuseppe MORABITO, Simona MUSAZZI, Gabriele A. TARTARI, Anna M. NOCENTINI, Alessandra PUGNETTI ${ }^{1)}$, \\ Roberta BETTINETTI ${ }^{2)}$, Pierisa PANZANI, Michele ARMIRAGLIO, Pierluigi CAMMARANO and Andrea LAMI \\ CNR Istituto per lo Studio degli Ecosistemi, Largo V. Tonolli 50, 28922 Verbania, Italy \\ ${ }^{1)}$ CNR Istituto di Scienze Marine, Sezione di Venezia, 1364 S. Polo, 30125 Venezia, Italy \\ ${ }^{2)}$ Università degli Studi dell'Insubria, Dip. Scienze Chimiche e Ambientali, Via Lucini 3, 22100 Como, Italy \\ *e-mail corresponding author: a.marchetto@ise.cnr.it
}

\begin{abstract}
Two small high mountain lakes in the Alps were monitored in 1984-2003 to follow their response to changes in human impact, such as deposition of atmospheric pollutants, fish stocking and climate change. The results were compared to occasional samplings performed in the 1940s, and to the remains found in sediment cores. When monitoring started, the most acid-sensitive of them, Lake Paione Superiore, was acidified, with evident effects in its flora and fauna: benthic diatoms assemblage was shifted towards acidophilous species, and zooplankton lost the dominant species, Arctodiaptomus alpinus. Palaeolimnological studies outlined that lake acidification paralleled the increasing input of long-range transported industrial pollutants, traced by spherical carbonaceous particles. On the contrary, the biota of Lake Paione Inferiore appeared to be mainly affected by fish stocking. In the last twenty years, decrease in acid load from the atmosphere led to an improvement in lake water quality, with an increase in both pH and alkalinity. First signs of biological recovery were identified, such as change in diatom flora and appearance of sensitive species among benthic insects. However, climate change and episodic deposition of Saharan dust were important driving factors controlling lake water chemistry. Further monitoring to assess the effects of climate change and of the increasing load of nitrogen and other pollutants is recommended.
\end{abstract}

Key word: atmospheric deposition, acidification, plankton, benthos, diatoms

\section{INTRODUCTION}

The Paione lakes are three cascade lakes of glacial origin located in a small valley in the southern part of Central Alps. They were first studied in the 1940s by Vittorio Tonolli, who carried out detailed studies on them, with a pioneering multidisciplinary approach integrating climatic and morphometric properties of the watersheds and chemical analysis of lake water for an interpretation of the biological features of the lakes (Tonolli 1949). These studies represented a pilot research which led to the organisation of a survey covering 170 lakes throughout the Italian Alps (Tonolli \& Tonolli 1951), that produced a full picture of the plankton in Alpine lakes, and an account of the relationships between the biological communities and the main environmental parameters of the lakes and their watersheds. At that time, mountain lakes appeared to be far from human influence, and they were studied to establish reference conditions for the lowland, more polluted lakes, or to examine ecological processes without taking into account the effects of the direct anthropogenic disturbances, such as local pollution or land use change.

It was in 1981, after a second survey covering 300 alpine lakes (Giussani et al. 1986), that human activity appeared to be a major factor affecting high mountain lakes: inappropriate fish stocking, without any scientific basis, was found to have the most striking impact on Alpine lakes, including Lake Paione Inferiore (LPI), the lower Paione lake. Acid deposition was a concern for a small, but significant number of the sampled lakes: $5 \%$ of them showed pH values below 6.0 (Mosello 1984). Lake Paione Superiore (LPS), the upper Paione lake, resulted to be one of the most acid lakes, because of the lithological characteristics of its watershed, and of the high acid load from atmospheric deposition (Mosello et al. 1999).

For these reasons, both LPI and LPS were chosen as flag-ship sites in several research programmes aiming to quantify the effects of acid deposition and other anthropogenic impacts on mountain lakes and their biota, namely "Quantification of the susceptibility of Alpine lakes to acidification" (1988-1991), "AL:PE, Acidification of mountain Lakes: Palaeolimnology and Ecology" (1991-1994), "MOLAR: MOuntain LAkes Research" (1996-99) and "EMERGE: European Mountain lakes Ecosystems: Regionalisation, diaGnostic and socio-economic Evaluation" (2000-2003). These projects focused on high altitude environments, considered good indicators of the effects of atmospheric pollution on a regional 
scale, and of climate change (Wathne et al. 1995, 1997; Patrick et al. 1998; Kernan \& Catalan 2003).

In this paper, we present a synthesis of the results obtained through 20 years of monitoring of the Paione lakes, showing the effects of lake acidification and the recent signs of recovery, related to the reduction of the deposition of acidifying substances which followed the adoption of the Convention on Long-Range Transboundary Air Pollution signed in Geneva in 1979. The effects of climate change and other confounding factors on chemical and biological recovery are also discussed. Full description of the discussed data and detail on the sampling stategies and analytical methods can be found elsewhere (Bertoni et al. 2002; Boggero \& Nocentini 1994; Cammarano \& Manca 1997; Guilizzoni et al. 1996; Manca \& Armiraglio 2002; Mosello et al. 1999; Pugnetti \& Bettinetti 1992, 1995; Tonolli 1949).

\section{DESCRIPTION OF STUDY SITES}

The Paione lakes are located in the Bognanco Valley, in the Central Alps (Pennine) in Piedmont (Italy) (Fig. 1). They are glacial lakes and form part of a system consisting of three lacustrine environments. Their watersheds are not affected by any anthropogenic disturbance or soil use. The lakes are usually ice-covered from the beginning of November to mid-June. From a geo-lithological point of view, most of the catchment is made up of clear banded orthogneiss and grey gneiss, while small amounts of micaschists and calceschists are present in the catchment of the lower Paione lake (LPI). The land cover is mainly alpine meadow, which is restricted to small areas, most of the watershed surface being characterised by bare rocks and debris. The main geographical and hydrological characteristics of the watersheds of the two major Paione lakes are presented in table 1. A soil survey performed in 2000 allowed to collect detailed information about soils in their catchment: lying on acidic bedrocks, the soils are acidic, with low base saturation and an exchange complex dominated by hydrogen and aluminium ions (Rogora et al. 2001).

\section{SAMPLING AND METHODS}

Available chemical data on Paione lakes cover a period of about 20 years, though with a different sampling frequency from year to year (Tab. 2). Samples for chemical analysis were collected near the deepest point of each lake, at the end of summer and, from 1984 to 1988, during the snowmelt; from 1991 to 1999 sampling was performed also in winter; then, since 2000, only one or two samples per year have been collected in late summer/autumn. As no stable thermal stratification was detected in the lakes, mean values using a weighted average based on the water volume at different depths were calculated.

All the samples have been analysed for $\mathrm{pH}$, conductivity, alkalinity (acidimetric titration, Gran's method), main anions (sulphate, nitrate and chloride) by ion chromatography, main cations (calcium, magnesium, sodium and potassium) by atomic adsorption and, from 1991, by ion chromatography; ammonium, reactive silica and reactive and total phosphorus by spectrophotometry (indophenol-blue and ammonium molibdate with ascorbic acid respectively). Analytical methods were carefully evaluated to assure the comparability of the data, as some changes in analytical methods were introduced during the period (Tartari \& Mosello 1997).
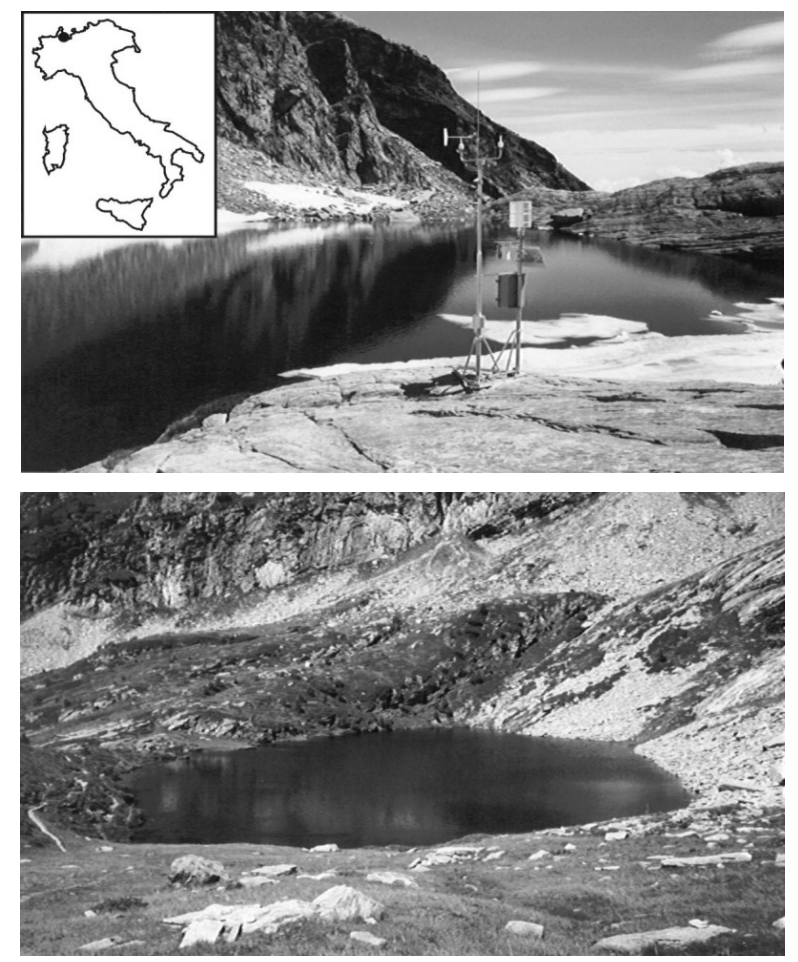

Fig. 1. Lake Paione Superiore (above) and Lake Paione Inferiore (below) and map showing their location.

Phytoplankton samples were immediately fixed using Lugol's solution, counting was performed on $25 \mathrm{ml}$ subsamples using the inverted microscope at $400 \times$ on 100 randomly selected fields (Sandgren \& Robinson 1984). Zooplankton samples were collected with a 126 $\mu \mathrm{m}$ mesh size plankton net: vertical hauls were made in the central zone of the lakes. The samples were immediately fixed using alcohol 95\% (Hall 1964) and then transferred into formalyn $10 \%$. Most samples were counted entirely, under a compound microscope, using a $1 \mathrm{~mm}$ Hydro-Bios Kiel counting chamber.

Qualitative kick sampling for macrobenthos was performed during the ice-free season using an hand-net (225 $\mu \mathrm{m}$ mesh aperture) and following the methodologies proposed by Frost et al. (1971) and Storey et al. (1991) and summarised in the EMERGE protocol (Fjellheim et al. 2000a). When pupal exuviae were present, the surface water was skimmed with the same net. In most of the cases, this technique made identification to species level possible. The two lakes were sampled in 
Tab. 1. Main characteristics of the Paione lakes and their catchments.

\begin{tabular}{lccccccc}
\hline & $\begin{array}{c}\text { Altitude a.s.l } \\
(\mathrm{m})\end{array}$ & $\begin{array}{c}\text { Mean depth } \\
(\mathrm{m})\end{array}$ & $\begin{array}{c}\text { Max depth } \\
(\mathrm{m})\end{array}$ & $\begin{array}{c}\text { Mean precipitation } \\
\left(\mathrm{mm} \mathrm{y}^{-1}\right)\end{array}$ & $\begin{array}{c}\text { Renewal time } \\
(\text { days })\end{array}$ & $\begin{array}{c}\text { Yearly mean discharge } \\
\left(\mathrm{l} \mathrm{s}^{-1} \mathrm{~km}^{-2}\right)\end{array}$ & Land cover \\
\hline LPS & 2269 & 5.1 & 11.5 & 1400 & 33 & 44 & $\begin{array}{c}\text { Bare rocks }(72 \%) \\
\text { soil (28\%) } \\
\text { Bare rocks (61\%) } \\
\text { soil (39\%) }\end{array}$ \\
LPI & 2202 & 7.4 & 13.5 & 1450 & 23 & 46 & \\
\hline
\end{tabular}

Tab. 2. Sampling frequencies and depths. L: littoral, O: outlet *: depth of the last sample was adjusted to be close to the bottom (for chemistry) or $1 \mathrm{~m}$ above the bottom (for phytoplankton).

\begin{tabular}{|c|c|c|c|c|c|}
\hline \multirow[t]{2}{*}{ Year } & \multicolumn{2}{|c|}{ Chemistry } & \multirow{2}{*}{$\begin{array}{c}\text { Phyto \& Zooplankton } \\
\text { Frequency }\end{array}$} & \multirow{2}{*}{$\begin{array}{l}\text { Phytoplankton } \\
\text { depth* }\end{array}$} & \multirow[t]{2}{*}{ Benthos } \\
\hline & frequency & depth* & & & \\
\hline \multicolumn{6}{|l|}{ LPS } \\
\hline 1946 & & & once in July & & \\
\hline $1984 / 6$ & twice in Summer & $1,5,8 \mathrm{~m}$ & & & \\
\hline $1987 / 90$ & once in Autumn & $1,5,8 \mathrm{~m}$ & & & \\
\hline 1991 & monthly from June & $1,5,8 \mathrm{~m}$ & monthly from June & integrated & monthly ice-free (L) \\
\hline 1992 & monthly & $1,5,8 \mathrm{~m}$ & monthly & integrated & monthly ice-free (L) \\
\hline 1993 & monthly & $1,5,8 \mathrm{~m}$ & monthly & integrated & once in July (L) \\
\hline 1994 & monthly ice-free & $1,5,8 \mathrm{~m}$ & & & seasonal ice-free $(\mathrm{L}+\mathrm{O})$ \\
\hline 1995 & twice in Summer & $1,5,8 \mathrm{~m}$ & & & seasonal ice-free $(\mathrm{L}+\mathrm{O})$ \\
\hline 1996 & monthly from July & $1,5,8 \mathrm{~m}$ & monthly from July & $1,7 \mathrm{~m}$ & seasonal ice-free $(\mathrm{L}+\mathrm{O})$ \\
\hline 1997 & monthly & $1,5,8 \mathrm{~m}$ & monthly & $1,7 \mathrm{~m}$ & monthly ice-free $(\mathrm{L}+\mathrm{O})$ \\
\hline 1998 & monthly upto Oct. & $1,5,8 \mathrm{~m}$ & monthly upto Oct. & $1,7 \mathrm{~m}$ & \\
\hline 1999 & monthly & $1,5,8 \mathrm{~m}$ & & & \\
\hline 2000 & twice in Summer & $1,5,8 \mathrm{~m}$ & once in Sep. & $7 \mathrm{~m}$ & once in September $(\mathrm{L}+\mathrm{O})$ \\
\hline \multicolumn{6}{|l|}{ LPI } \\
\hline 1946 & & & once in July & & \\
\hline $1984 / 6$ & monthly ice-free & $1,6,12 \mathrm{~m}$ & & & \\
\hline 1987 & twice in Summer & $1,6,12 \mathrm{~m}$ & & & \\
\hline 1988/90 & once in Autumn & $1,6,12 \mathrm{~m}$ & & & \\
\hline 1991 & monthly from June & $1,6,12 \mathrm{~m}$ & monthly from June & integrated & monthly ice-free $(\mathrm{L}+\mathrm{O})$ \\
\hline 1992 & monthly & $1,6,12 \mathrm{~m}$ & monthly & integrated & once in July $(\mathrm{L}+\mathrm{O})$ \\
\hline 1993 & monthly & $1,6,12 \mathrm{~m}$ & monthly & integrated & once in September $(\mathrm{L}+\mathrm{O})$ \\
\hline 1994 & monthly ice-free & $1,6,12 \mathrm{~m}$ & & & seasonal ice-free $(\mathrm{L}+\mathrm{O})$ \\
\hline 1995 & twice in Summer & $1,6,12 \mathrm{~m}$ & & & \\
\hline 1996 & monthly from July & $0 \mathrm{~m}$ & monthly from July & $1,11 \mathrm{~m}$ & \\
\hline 1997 & monthly & $0 \mathrm{~m}$ & monthly & $1,11 \mathrm{~m}$ & \\
\hline 1998 & monthly upto Oct. & $0 \mathrm{~m}$ & monthly upto Oct. & $1,11 \mathrm{~m}$ & \\
\hline 1999 & monthly ice-free & $0 \mathrm{~m}$ & & & \\
\hline 2000 & twice in Summer & $1,6,12 \mathrm{~m}$ & & $11 \mathrm{~m}$ & once in September $(\mathrm{L}+\mathrm{O})$ \\
\hline
\end{tabular}

more than one station on the shore (different substrata) and at their outlets (lake source and 100-200 m downstream).

Diatom assemblages were analysed in surface sediment samples collected in 1989 and 2000: short cores were taken in the deepest part of both lakes using a gravity corer, and sectioned in 10 and $5 \mathrm{~mm}$ slices, respectively. A small amount of sediment was cleaned using standard techniques (Rendberg 1990) and counted under oil immersion at a magnification of $1000 \times$. Given the sedimentation rate of $c a 0.7 \mathrm{~mm} \mathrm{y}^{-1}$ (Guilizzoni et al. 1993), the surface samples include sediment representing around 15 and 7 years, for the older and more recent core, respectively.

\section{DRIVING FACTORS}

\subsection{Trends in the chemistry of atmospheric deposition}

Two atmospheric deposition sampling stations are located in the area of Paione lakes: Graniga, located in the Bognanco valley, at $1113 \mathrm{~m}$ a.s.l., about $5 \mathrm{~km}$ from the lakes, and Domodossola, at the mouth of the same valley, at $270 \mathrm{~m}$ a.s.l. Both sites are equipped with wetonly collectors and samples are collected weekly and analysed for the major chemical variables. At Graniga sampling started in 1994, while data for Domodossola are available since 1986. Data collected at the two sites proved to be very similar both for precipitation amount and the major ions (Mosello et al. 1999). Hence data from Domodossola can be used to investigate trends in the chemistry of atmospheric deposition affecting the area of Paione lakes. Sulphate concentration in rain showed a marked decrease, from 55-60 $\mu \mathrm{eq} \mathrm{l}^{-1}$ in the second half of the 1980 s to $25-30 \mu \mathrm{eq}^{-1}$ in recent years. As a consequence, $\mathrm{pH}$ increased significantly from about 4.4 to $4.9-5.0$.

A slight decrease in the concentrations of base cations (BC) was also detected. On the other hand, the atmospheric deposition of inorganic $\mathrm{N}$ (about $15 \mathrm{~kg} \mathrm{~N}$ $\mathrm{ha}^{-1} \mathrm{y}^{-1}$ as sum of ammonium and nitrate) did not show any significant trend in the study period (Rogora et al. 2001). 
The decreasing trend in $\mathrm{SO}_{4}{ }^{2-}$ concentration is characteristic of other sampling stations in the same area and is also confirmed by the data available for other sites in northern Italy (e.g. Tait \& Thaler 2000). Data on atmospheric emissions in Italy over the last 20 years (ANPA 1999) indicate a decrease of $\mathrm{SO}_{2}$ emission from $3.7 \times 10^{6}$ to $1.3 \times 10^{6} \mathrm{t} \mathrm{y}^{-1}$, mainly due to the reduction in $\mathrm{S}$ oxide emissions from thermoelectric power plants (which represent $62 \%$ of the total anthropogenic emissions in Italy) and industrial production (24\%). On the other hand, the emission of $\mathrm{N}$ compounds remained fairly constant: $\mathrm{NH}_{3}$ emissions were stable at about $0.510^{6} \mathrm{t} \mathrm{y}^{-1}$ in the last 15 years, while $\mathrm{N}$ oxides increased slightly from 1986 to 1992 and then decreased in 1993-95.

\subsection{Metereological parameters}

An Automatic Weather Station (AWS) was installed in 1997 and is still in operation thanks to the co-operation with Regione Piemonte, Servizio meteo-idrografico. Measured variables are: air temperature, relative humidity, solar radiation, wind speed and direction, and precipitation amount. Parameters are measured every 10 minutes, stored and then transferred via radio as mean hourly values. Unfortunately the available data do not cover a time period long enough to evaluate possible trends in meteorological data and their effect on lake chemistry.

Much of the variability in air temperature at upland sites can usually be explained by air-temperature series collected at lowland stations located within a range of $400 \mathrm{~km}$ (Agustí-Panareda et al. 2000). Several meteorological stations in the area of Paione lakes are in operation since the beginning of the 1900s. In particular a long-term series of air temperature data (since 1870) is available for the station located in the town of Domodossola (Lami et al. 2002). These data proved to be well correlated to those collected by the AWS at LPS in 1997-2002 $\left(\mathrm{R}^{2}=0.93, p<0.001\right)$. The long-term trend of mean air temperature (as anomalies from the longterm mean of the period 1870-2003) at Domodossola is shown in figure 2. An upward trend seems to be occurring since 1970. The 1990s were the warmest decade of the whole record. The highest values of the period were recorded in 1992 and 2003.

No trend was found in precipitation amount recorded at the meteorological stations, even though a more detailed analysis of the data revealed an increasing occurrence of stormy precipitation events in the last decades (Maugeri et al. 2002). Data about snow cover available for a few sites did not show a univocal trend, even though a decrease of snow depth and duration has been detected in the last 15 years (Rogora et al. 2003). These trends agree with the results provided by the Intergovernmental Panel on Climate Change (IPCC), showing a sharp increasing trend of global surface temperature in the last 25-30 years. The effects of climate warming seem to be of major importance in areas subject to ice or snow cover (IPCC 2001).

\section{TRENDS IN LAKE CHEMISTRY}

LPS and LPI are characterised by dilute water, with a very low ionic content (140 and $220 \mu \mathrm{eq} \mathrm{I}^{-1}$, respectively as mean values for the period 2000-2003) and conductivity of about 9 and $13 \mu \mathrm{S} \mathrm{cm}{ }^{-1}$ at $20{ }^{\circ} \mathrm{C}$, respectively. Previous studies on seasonal variations of lake chemistry showed how ionic concentrations reach their minimum at the end of the snowmelt period, owing to the dilution effect of the melting ice (Mosello et al. 1999).

Calcium, magnesium and sodium are the most important cations for both lakes, while sulphate and nitrate are the dominant anions. Ammonium concentrations are always very low, due to vegetation uptake and bacterial oxidation. The main difference between the two lakes is in the $\mathrm{pH}$ values and in the concentrations of alkalinity and base cations (BC). The explanation can be found in the lithological composition of lake catchments. Acidic, low-weathering rocks (clear banded orthogneiss and grey gneiss) are dominant in both catchments, but in the case of LPI also small amounts of more soluble minerals, such as micaschists, are present. As a consequence, LPS proved to be more sensitive to acidic inputs than LPI, where the weathering of soils and rocks in the catchment caused the total neutralisation of atmospheric acidity (Mosello et al. 1999).

Trends of selected chemical variables since 1984 are shown in figure 3. Only samples collected in late summer or early autumn have been considered here. Both lakes experienced a recovery from acidification since the 1990s, particularly evident in LPS. There was a marked increase in $\mathrm{pH}$ for both lakes. LPS had $\mathrm{pH}$ values between 5.3 and 5.8 before 1992; in the last three years the values have been near or slightly above 6.0, with a peak of 6.4 in 2003. In LPI, pH has been always above 6.0, and in recent years it increased to about 6.5 (6.8 in 2003) (Fig. 3). Alkalinity values in LPS followed the increasing trend in $\mathrm{pH}$ : they were close to zero or negative in the period 1984-1994, and then started to increase (Fig. 3) up to an average of $9 \mu \mathrm{eq} \mathrm{l}^{-1}$ in the last few years (2000-2003). A similar pattern led to a present mean alkalinity of $40 \mu \mathrm{eq} \mathrm{l}^{-1}$ in LPI.

Beside the increase in $\mathrm{pH}$ and alkalinity, a further evidence of the recovery from acidification in LPS can be found in the trend of aluminium (Al) concentrations (Fig. 3). Despite marked seasonal fluctuations, Al content in lake water decreased from $60-70 \mu \mathrm{g} \mathrm{l}^{-1}$ in the 1980 s to $15-20 \mathrm{\mu g}^{-1}$ in recent years. In LPI, where an acidified status was never reached, $\mathrm{Al}$ concentrations remained fairly stable $\left(10-20 \mu \mathrm{g} \mathrm{l}^{-1}\right)$ overall the study period.

Recovery from acidification in Paione lakes is mainly related to the marked decrease of $\mathrm{SO}_{4}{ }^{2-}$ deposition detected in the lake area during the last two decades, which resulted in a significant decrease of $\mathrm{SO}_{4}{ }^{2-}$ concentrations in both lakes. 


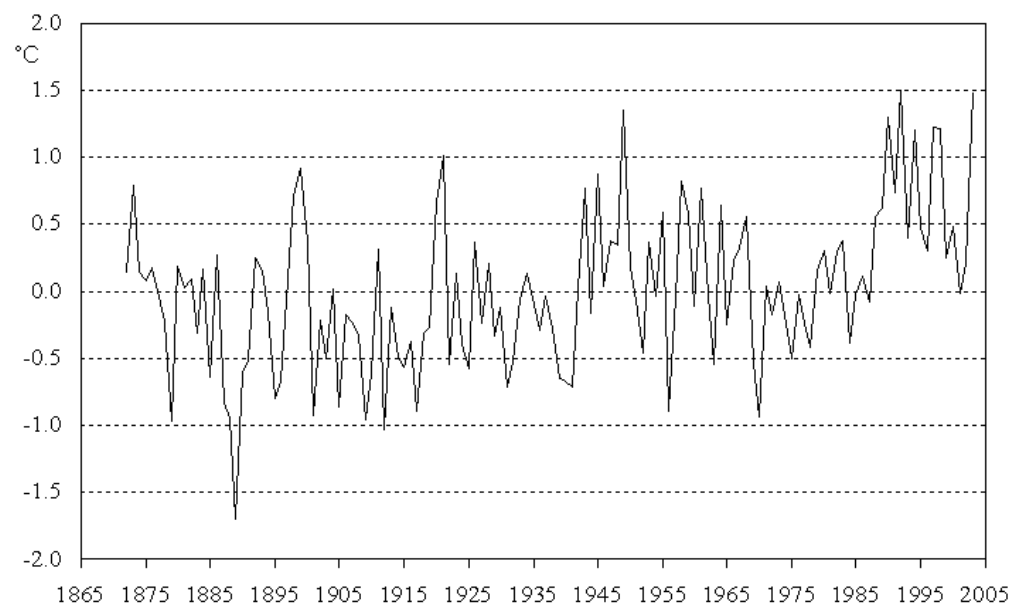

Fig. 2. Trend of air temperature (anomalies from the long-term mean value of 1870-2003) at Domodossola.
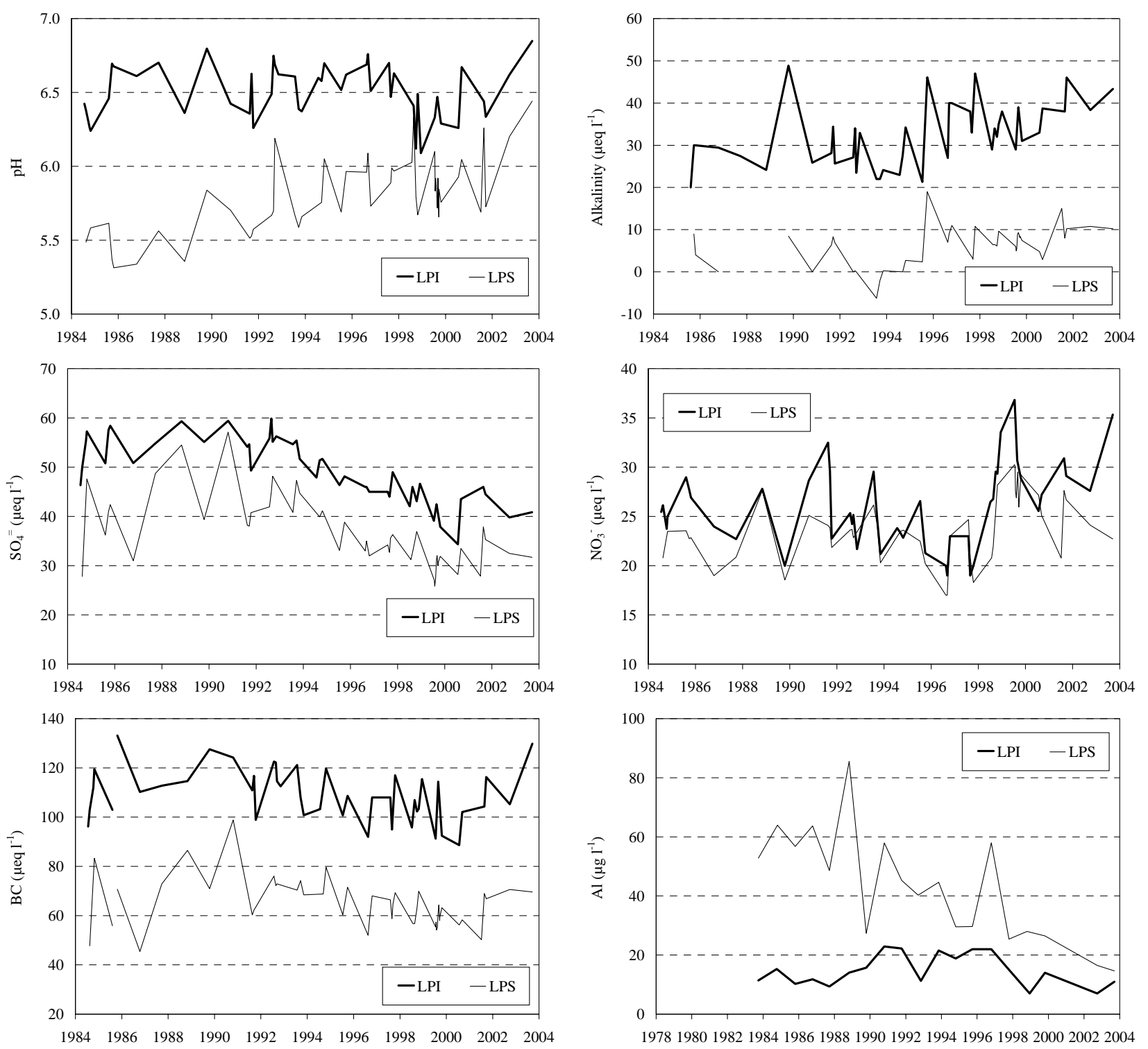

Fig. 3. Trends of selected chemical variables in the Paione lakes in the period 1984-2003 (only samplings performed in late summer or early autumn are considered). BC: base cations. 
On the other hand, $\mathrm{NO}_{3}{ }^{-}$content has not significantly changed, even though a slightly increasing trend has been detected in both lakes since the middle of the 1990s (Fig. 3). Nitrate concentrations in Paione lakes (29 and $25 \mu \mathrm{eq}^{-1}$ in LPI and LPS, respectively) are quite high compared to those found in other remote lakes in Europe (The MOLAR Water Chemistry Group 1999; Mosello et al. 2002).

Several sites in the subalpine area South of Paione lakes showed significant positive trends of $\mathrm{NO}_{3}^{-}$concentrations in the last two decades, as an effect of $\mathrm{NO}_{3}{ }^{-}$ leaching from $\mathrm{N}$ saturated soils (Rogora et al. 2001). This process may be hypothesised to explain the increasing concentrations of $\mathrm{NO}_{3}{ }^{-}$in LPS and LPI in the last few years. If $\mathrm{N}$ deposition remains at present level, several high altitude lakes in the alpine area could approach a condition of $\mathrm{N}$ saturation in the next future.

Other factors besides atmospheric deposition affect the hydrochemistry of alpine lakes and its change in time. Previous studies on alpine lakes in Central-Western Alps showed how meteorological parameters, mainly precipitation amount, play a relevant role in the chemistry of the lakes (Rogora et al. 2003). The dilution effect causes low concentrations of solute in the lakes in correspondence of wet years. On the other hand, peaks in the concentrations of ions deriving from weathering processes are usually detected after dry periods. Also the role played by air temperature, which has a marked effect on the weathering processes of rocks and soils in the catchments, might not be negligible (SommarugaWögrath et al. 1997).

Temperature and precipitation together could explain the maximum values of $\mathrm{pH}$, alkalinity and base cations recorded in both Paione lakes in 2003 (Fig. 3). That year was characterised by a very dry and hot summer: mean values of precipitation amount $(103 \mathrm{~mm})$ and air temperature $\left(7.8^{\circ} \mathrm{C}\right)$ in the period July-October were steadily different from the long-term averages for this site (about $1000 \mathrm{~mm}$ and $6.9^{\circ} \mathrm{C}$ ). The effect of meteorological factors is usually more evident in LPI, owing to the presence of more weatherable rocks in the catchment. As an example, the high summer temperature and scarce precipitation of 1989 and 2003 caused the relative maxima of $\mathrm{pH}$, alkalinity and $\mathrm{BC}$ in this lake (Fig. 3).

A further factor influencing lake chemistry is the episodic deposition of Saharan dust, which can neutralize the acidic input associated with atmospheric deposition and represents an important source of alkalinity and nutrients to alpine lakes (Psenner 1999). Long-term series of atmospheric deposition data from Domodossola and other sites in the same area suggest an increased occurrence and intensity of alkaline precipitation events in recent years (Rogora et al., in press). This could account for the recent upward trend of $\mathrm{pH}$, alkalinity and $\mathrm{BC}$ in Paione lakes (Fig. 3).

\section{THE RESPONSE OF LAKE BIOTA}

\subsection{Phytoplankton}

The changes of phytoplankton assemblages of Paione lakes were studied in detail during the decade 1991-2000, although with some breaks in the years 1994, 1995 and 1999. This series of data is probably unusual for an alpine lake, where the climatic conditions make often difficult to take samples with high periodicity. The data available allow to outline some basic features of the algal biocoenosis in Paione lakes, although an evolutionary trend can not be clearly detected, due to some differences in the sampling strategy and periodicity, coupled with the year-to-year variability of the alpine environment.

The climatic and chemical characteristics of the Paione lakes allow short, rapid growth periods of the phytoplankton. The general features of the algal assemblages in Paione lakes mirror those described years ago by Pechlaner (1971) for the high altitude lakes: dominance of nannoplanktonic flagellates, low number of taxa, low qualitative seasonal variations, low mean yearly biomass, rapid and quite high biomass peaks. In each of the three surveys carried out during the last decade (1991-93; 1996-98: Pugnetti \& Bettinetti 1995, 1999; 2000: Morabito \& Panzani unpublished data), because of the poor quality of the material examined, it was impossible to identify the phytoplankton taxa at a level higher than genus, with the only exception of the chrysophyte Mallomonas alveolata. Due to this reason, a comparison of the phytoplankton assemblages across the decade must be done very carefully.

The studies carried out in 1991-93 (Pugnetti \& Bettinetti 1995) and 1996-98 (Pugnetti \& Bettinetti 1999) analysed in detail the phytoplankton succession in Paione lakes, whereas in 2000 a single sample was gathered in September. A common trait of the algal biocoenosis in Paione lakes is the dominance of the flagellated forms: among them Mallomonas alveolata, Dinobryon spp., Chromulina sp. and Gymnodinium spp. characterised the phytoplankton assemblages during all the three campaigns. Together with these algae, the chlorophytes Chlamydomonas spp. were found in 1991'93 and 1996-98, whereas only in the two most recent surveys (1996-98 and 2000) Cryptomonas spp. were recorded.

Among the non motile algae, the chlorophytes Monoraphidium spp. and Tetraedron spp. reached a certain importance. Moreover, it should be mentioned the finding of some diatom taxa in the plankton during the 1996-98 investigation (Pugnetti \& Bettinetti 1999), perhaps the most relevant change in the decade 19912000. A past paleolimnological investigation (Guilizzoni et al. 1996) showed an increase of diatom species at the beginning of the 1990s in LPS; however, most of the taxa found were acidophilous or acidobiontic, indicating a trend of the lake towards acidification. 
The most recent findings seem, on the contrary, to indicate a reversion of this trend: as Pugnetti \& Bettinetti (1999) pointed out, the increased importance of the diatoms inside the planktonic community, coupled with a higher phytoplankton diversity, follows an increase of $\mathrm{pH}$ and alkalinity in Paione lakes (see also The MOLAR Water Chemistry Group 1999). Their identification of the planktonic diatoms at the genus level limits, however, a better understanding of the evolutionary trend. In fact, the genera of planktonic diatoms (Achnantes, Aulacoseira, Cyclotella and Stephanodiscus) found by Pugnetti \& Bettinetti (1999) were, except for Stephanodiscus sp., already present in the list of acidophilous and acidobiontic diatoms reported in Guilizzoni et al. (1996).

Unfortunately, the single sample taken during September 2000 can not confirm that new rearrangement of the phytoplankton assemblage, although showing a species composition similar to that of September 1996, '97 and '98, dominated by Chrysochromulina sp. and Dinobryon sp.: the peak of diatom growth probably took place earlier, maybe during July or August, as observed in 1996-98.

Quite usual in Paione lakes is also the development of a significant phytoplankton population under the ice cover, typically dominated by Chrysochromulina sp. and Dinobryon sp., together with Mallomonas alveolata and Gymnodinium sp. in 1991-93. The growth of phytoplankton under a thick ice layer is a well known phenomenon: for instance Rhode (1955) already reported a similar pattern in subarctic lakes, explaining it with the hypothesis of a heterotrophic metabolism of the algae. The facultative mixotrophic metabolism is typical of both Chrysochromulina sp. and Dinobryon sp. (Isaksson 1998), the two most important taxa in Paione lakes: their heterotrophy was already hypothesised during the 1996-'98 survey (Callieri et al. 1999) and definitely confirmed in 1999 through the grazing experiments conducted by Bertoni et al. (2002) in LPS.

In summary, as far as we can speculate, the most recent structure (September 2000) of the phytoplankton assemblage resembles that observed during 1996-98, whose basic characteristics were outlined in previous works (Pugnetti \& Bettinetti 1999). The algal biocoenosis is dominated by 2-3 species of nannoplanktonic flagellates with mixotrophic properties; it is quite usual to have the maximum yearly development during winter, under a thick under ice cover (especially in LPS); the late summer algal development in LPS is strongly controlled by the grazing pressure of Daphnia longispina. The increased importance of the diatoms in the plankton, recorded by Pugnetti \& Bettinetti (1999), probably deserves a further investigation, because the most recent survey does not allow to confirm their statement.

\subsection{Zooplankton}

Studies on zooplankton of the Paione lakes have been carried out since the middle of the '40s (Tonolli
1949, Tonolli \& Tonolli 1951), with occasional samplings during the ice-free period. It was in 1992 that a more regular sampling strategy was established. After a two-years period of sampling (1992-1993), including the ice-cover phase, the lakes appeared to have lost one of the species characterizing the former zooplankton community, namely Arctodiaptomus alpinus (Fig. 4a and b) (Cammarano \& Manca 1997); the disappearance was attributed to water acidification, conforming with literature information reporting a gradual decrease in abundance of this calanoid copepod with decreasing $\mathrm{pH}$ values (Fott et al. 1994). Most variations in zooplankton species composition and abundance are known to occur in the $\mathrm{pH}$ range between 5 and 6 (Brezonik et al. 1984; Watras \& Frost 1989; Locke \& Sprules 1994), the range found in the Paione lakes.
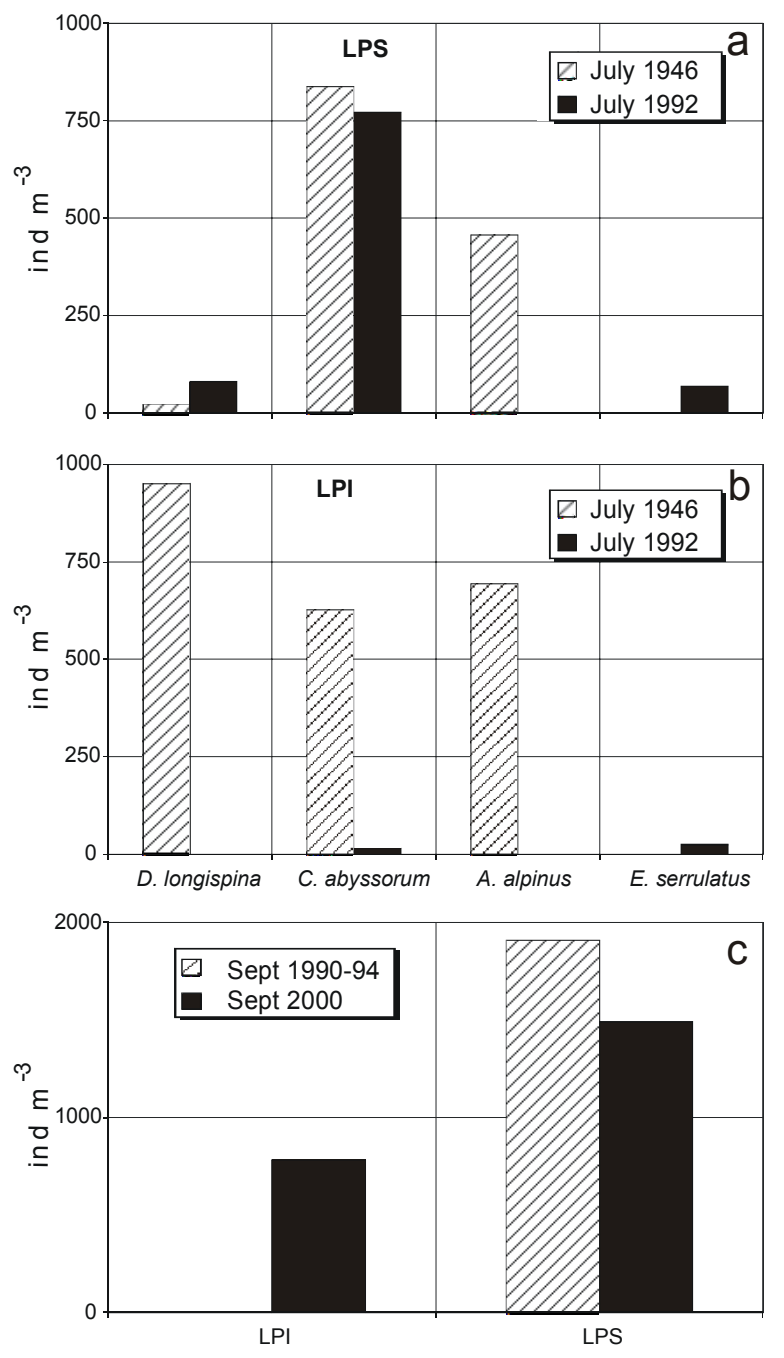

Fig. 4. Crustacean zooplankton of the Paione lakes: (a) comparison of the community before (AD 1946) and after (AD 1992) the introduction of fish, and (b) of Daphnia population density (c) before (1990-1994) and after (2000) stopping fish introduction. 
In the less acidic LPI, all crustacean zooplankton had disappeared; the extreme impoverishment was attributed to fish stocking (Cammarano \& Manca 1997), and this hypothesis was verified by an analysis of cladoceran remains in a sediment core dating back to the beginning of the $19^{\text {th }}$ century. The disappearance of Daphnia dated to the beginning of the 70s, when fish started to be introduced into the lake. It was also accompanied by an increase in chydorids of small $(<10$ $\mathrm{um}^{3}$, Chydorus sphaericus) and intermediate sizes (10$100 \mathrm{\mu m}^{3}$, Alona quadrangularis and Acroperus harpae), which replaced large ones (Cammarano \& Manca, ibidem). A general decrease in size is consistent with the effects of fish predation.

Indeed, rainbow trouts were regularly introduced into the lake starting from the early '70s and this practice was still operating in 1991-1992 (Whatne et al. 1993). The practice of stocking allochtonous fish in high mountain lakes, though frequently unsuccessful because the stocked fishes do not usually reproduce or even survive, heavily affect the lakes (Tonolli \& Tonolli 1951; Giussani et al. 1986). Although being not strictly planktophagous at the adult stage, rainbow trouts are able to feed on zooplankton (Confer et al. 1978; Wright \& O'Brien 1982; O'Brien 1987). In addition, other smaller species were accidentally introduced, like Phoxinus phoxinus, a very efficient zooplankton-feeder which is normally present in Alpine lakes (Tortonese 1970).

Daphnia longispina reappeared in LPI in 2000 (Fig. 4c) (Manca \& Armiraglio 2002), after fish introduction was interrupted. Cyclops abyssorum also became very rare in LPI after fish introduction.

Indeed, the impact of fish introduction appeared stronger than that of acidification: despite the lower $\mathrm{pH}$, LPS apparently managed to maintain some of the traits of the zooplankton community observed in the past (Cammarano \& Manca 1997). The persistence of Daphnia longispina in relatively high numbers was attributed to its ability of developing acid-resistant morphs/clones (Schmidt et al. 1992).

However, it appeared surprising the persistence of both Daphnia and Cyclops at the extremely low average food concentrations of LPS: they had disappeared from mountain lakes in the High Tatra (Slovakia) acidified to the range of 4.9-6.3 $\mathrm{pH}$ units and with TP and chlorophyll- $a$ concentrations in the range of those found in LPS (category 2 lakes, Vihnalek et al. 1994). Their disapperance was attributed to starvation caused by a pH-driven ultraoligotrophication (Vihnalek et al. 1994). Their persistence in LPS could be explained by the relatively high values of chl- $a$ concentration under the ice-cover (Cammarano \& Manca 1997), when phytoplankton used to reach its maximum growth in this lake (Pugnetti \& Bettinetti 1995). While in LPI phytoplankton biomass was very low from the beginning of the ice formation until the ice-melting (Nov-Jun), and the growth of algae occured mainly in the ice-free period, in LPS the maximum development was observed under the ice-cover, when zooplankton was very low in biomass and Daphnia was rare.

The winter season resulted very important for the seasonal dynamic of LPS zooplankton: although the biomass and population density usually peaked in late August or September, reflecting the numerical increase of Daphnia (Fig. 5a), it appeared that the population was also reproductively active under the ice cover: parthenogenetic, ex-ephippio and ovigerous females were able to survive in addition to ephippial females.
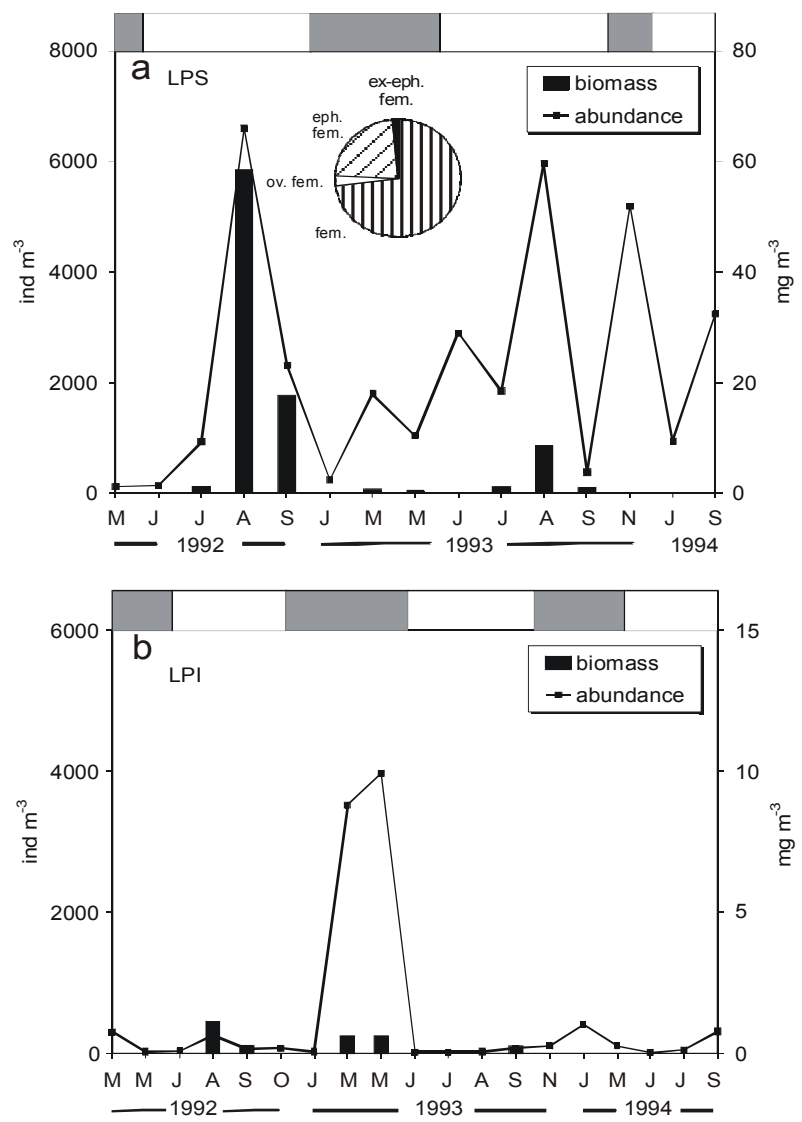

Fig. 5. Zooplankton population density (a) and biomass (dry weight) (b) in the Paione lakes in 1992-1994. The upper horizontal grey bars indicate the duration of ice-cover. The structure of Daphnia population under ice cover is also reported. fem.: partenogenetic females; ex eph. fem.: ex ephippio females; ov. fem.: ovigerous females; eph. fem.: ephippial females.

The seasonal cycle of the population of this cladoceran was not strictly univoltine, as more than one generation could be found in a single year. At the beginning of the ice-free period, parthenogenetic females became the most important component of the population; males appeared in August, reaching a maximum abundance in late September and October, when ephippial females also appeared (Cammarano \& Manca 1997). 
Tab. 3. Main groups and taxa characteristics for littoral and outlet stations for Paione lakes. xx: abundant; $x$ : present. Minimum and maximum values are shown.

\begin{tabular}{|c|c|c|c|c|}
\hline & \multicolumn{2}{|c|}{ LPS } & \multicolumn{2}{|c|}{ LPI } \\
\hline & littoral & outlet & littoral & outlet \\
\hline TURBELLARIA & & $3.1-9.1$ & $3.2-6.3$ & 2.1-10.0 \\
\hline LAMELLIBRANCHIA & & & 3.1-7.4 & \\
\hline OLIGOCHAETA & $6.7-33.3$ & 3.3-18.2 & $11.1-26.7$ & $5.9-44.4$ \\
\hline Enchytraeidae & $\mathrm{x}$ & $\mathrm{x}$ & $\mathrm{x}$ & $\mathrm{x}$ \\
\hline Lumbriculidae & $\mathrm{x}$ & & $\mathrm{x}$ & \\
\hline Naididae & & & $\mathrm{x}$ & \\
\hline Tubificidae & & & $\mathrm{x}$ & \\
\hline HYDRACARINA & $5.9-20.0$ & $3.3-20.0$ & $6.5-12.5$ & 4.3-11.4 \\
\hline AMPHIPODA & & $\mathrm{x}$ & & \\
\hline EPHEMEROPTERA & & & & 2.1-9.1 \\
\hline PLECOPTERA & & $10.0-23.1$ & $3.7-11.5$ & $5.0-17.6$ \\
\hline COLEOPTERA & 7.1-33.3 & & $3.3-4.0$ & $2.1-2.3$ \\
\hline MEGALOPTERA & & & 3.1-4.2 & $5.6-7.1$ \\
\hline TRICHOPTERA & $5.6-23.5$ & 3.9-18.5 & $3.1-15.4$ & $5.9-22.2$ \\
\hline DIPTERA & & & & \\
\hline Chironomidae & 22.2-71.4 & 33.3-62.5 & $36.0-58.3$ & $25.0-78.6$ \\
\hline Diamesinae & & $\mathrm{xx}$ & & \\
\hline Diamesa sp. & & $\mathrm{x}$ & & \\
\hline Tanypodinae & $\mathrm{xx}$ & & $\mathrm{x}$ & \\
\hline Psectrocladius spp. & & & $\mathrm{x}$ & \\
\hline Zavrelimyia sp. & $\mathrm{x}$ & & $\mathrm{x}$ & \\
\hline Orthocladiinae & $\mathrm{xx}$ & $\mathrm{xx}$ & $\mathrm{xx}$ & $\mathrm{xx}$ \\
\hline Corynoneura spp. & & & $\mathrm{x}$ & \\
\hline Corynoneura cf. lobata & & $\mathrm{x}$ & & $\mathrm{x}$ \\
\hline Eukiefferiella cf. brevicalcar & & $\mathrm{x}$ & & $\mathrm{x}$ \\
\hline Heleniella sp. & & $\mathrm{x}$ & & \\
\hline Heterotrissocladius marcidus gr. & $\mathrm{x}$ & & $\mathrm{x}$ & \\
\hline Krenosmittia sp. & & $\mathrm{x}$ & & \\
\hline Orthocladius (Eudactylocladius) & & & & $\mathrm{x}$ \\
\hline Chironominae - Tanytarsini & & & $\mathrm{xx}$ & $\mathrm{xx}$ \\
\hline Micropsectra spp. & $\mathrm{x}$ & & $\mathrm{x}$ & \\
\hline Paratanytarsus austriacus & $\mathrm{x}$ & & $\mathrm{x}$ & $\mathrm{x}$ \\
\hline
\end{tabular}

\subsection{Zoobenthos}

Until the '90s, benthos was not considered in high altitude lakes, except for faunistic purposes. The AL:PE project (1991-92) therefore represented the first attempt to provide a methodological description of the benthic fauna of these lakes in relation to chemical, geographical and morphological features. This paper includes fairly complete monitoring results for LPS, which was studied from 1991 to 2000; the data for LPI are more discontinuous, but to some extent more informative.

Up to now a total of 72 taxa (LPI) and 51 taxa (LPS), have been found in the lake-shore community. Chironomids are the most ubiquitous and the most abundant insect group in all types of freshwater in the Holarctic region (Pinder 1982). In fact, 32 taxa out of 72 in LPI and 26 out of 51 in LPS are Chironomids. This is also the most abundant group in high altitude lakes, constituting more than the half of the entire community. Only at ice-melt is their abundance low due to their emergence through cracks in the ice and snow cover, so that the samples at this time contain the largest numbers of their pupal exuviae.

Table 3 shows the distribution and minimum and maximum values for the main groups and taxa represented. Among Chironomids, Orthocladiinae, Tany- tarsini and Tanypodinae are the main families represented in both lakes, but the first two dominate in LPI, while Orthocladiinae and Tanypodinae are more important in LPS. The insect community of LPI is also represented by stoneflies (Nemoura cf. cinerea) and dobsonflies (Sialis cf. fulinginosa), and to a lesser extent by caddisflies. In LPS the absence of stoneflies and dobsonflies is striking, while caddisflies and water beetles are quite well represented. Chironomids share their dominance with oligochaetes, the second most important group in oligotrophic lakes. Water mites made up only a minor fraction of the community of both lakes, and bivalve mussels (Pisidium cf. casertanum) were observed only in LPI (Pugnetti et al. 1993; Boggero \& Nocentini 1994).

During the study period, 100 taxa (LPI) and 81 (LPS) were captured in the outlet stations. Chironomids were also dominant here, both as regard the number of taxa found (35/100 and 36/81, respectively), and their abundances (Tab. 3). The best represented Chironomids are the Orthocladiinae, followed by Diamesinae in LPS, and Tanytarsini in LPI. Stoneflies (Nemouridae and Leuctridae) and oligochaetes are quite well represented, while water mites and turbellarians appeared to be relatively uncommon. Of note is the presence in the outlet of LPS of the amphipod Niphargus sp., typical of un- 
derground streams; the outlet at the lake-source shows this characteristic. Secondly, it is important to point out that while mayflies appeared in autumn 1994 with only one species (Baetis sp.) $200 \mathrm{~m}$ downstream of LPI, in 2000 the presence of two species in the inlet and three $100 \mathrm{~m}$ downstream of the lake are an index of the upstream migration of species and of a more stable population. The contribution of the outlet is highly significant, both qualitatively and quantitatively, mostly on account of the input of turbellarians, stoneflies, water mites and large numbers of chironomids (Orthocladiinae) typical of flowing waters.

The results obtained suggest that species richness is still poor in the two lakes, especially in LPS, due to physico-chemical conditions that restrict animal survivorship to a few species highly adapted to extreme environments. This emerges more clearly if we consider the differences between the two lakes. In fact, LPI, with its longer ice-free period, higher temperatures and trophic level seems to be mainly influenced by hydro-chemistry and fish stocking. The latter is a major cause of lake impoverishment, mainly affecting Limnephilidae, Baetidae and Heptagenidae, a favoured food source for fishes at the larval stage (Bertrand 1954; Bradford et al. 1998). In contrast, the ultra-oligotrophic LPS appears to be strongly affected by climatic conditions, so that chemistry plays only a subordinate/minor role, and thermal features lessen colonisation rates causing an impoverishment of the lake (Wathne et al. 1997; Fjellheim et al. 2000b).

Moreover, the inlet and outlet of LPI, owing to the influence of the lakes upstream, are characterised by more stable and heterogeneous banks and stream bed, and receive a higher food supply, so that a larger and more varied community is present here respect to the inlet and the outlet of LPS, typically situated on a poor and coarse substratum (Hieber et al. 2002). Consequently, the inlet and outlet of LPI contain a higher number of sensitive taxa and a more diverse fauna than those of LPS (23\% and 41\% more taxa in the outlet and the littoral stations, respectively).

\subsection{Benthic diatoms}

In LPS, diatom assemblages was dominated in 1989 by small Achnanthes (A. curtissima, A. lacus-vulcani, $A$. marginulata, $A$. helvetica and $A$. scotica, summing up to $30 \%$ of the overall diatom count) and by specimen of the $P$. microstauron/caudata group, such as $P$. isselana and $P$. miscrostauron var. nonfasciata (totaling 18\%). Aulacoseira alpigena was also common (11\%). The composition of the diatom assemblage was typical of a clearwater, oligotrophic, acid lake.

In the same lake, the diatoms found in 2000 were still dominated by the same Achnanthes (15\%) and Pinnularia (8\%) species, but the alkaliphylous Aulacoseira valida (11\%) and Achnanthidium minutissimum (11\%) were also present, testifying the response of the diatom community to the improving chemical conditions of the LPS.
In 1989, LPI was dominated by the same Achnanthes (48\%) and Pinnularia (10\%) species, followed by Pseudostaurosira pseudoconstruens (10\%), Aulacoseira italica (8\%), and Achnanthidium minutissimum (6\%). However, in 2000, 29\% of the diatom valves found belonged to Aulacoseira distans var. distans, while the rest of the assemblage was similar to that found eleven years before, still composed by the same Achnathes (25\%) and Pinnularia (10\%) species. In contrast to LPS, in LPI a shift towards more alkaliphylous diatoms was not evident.

\section{PALAEOLIMNOLOGICAL PERSPECTIVE}

Palaeolimnological analyses were performed on several short cores ( $c a 0.5 \mathrm{~m}$ ) taken with a gravity corer between 1989 and 2000. The primary goal of such studies was to verify if the lakes were naturally acid, or if they were acidified by the atmospheric acid load. Most of the studies dealt with LPS, and were summarized by Guilizzoni et al. (1996).

Diatom analysis revealed the intensity and temporal trend of lake acidification. Diatom-inferred $\mathrm{pH}$ decreased by around 0.4 units in the topmost $3 \mathrm{~cm}$ of the core taken in 1999. On the basis of absolute dating using ${ }^{210} \mathrm{~Pb}$ and ${ }^{137} \mathrm{Cs}$, the onset of LPS acidification was dated back to 1960 and 1970 .

In the second half of the $20^{\text {th }}$ century, starting in 1945-1956, an increase in the concentration of Spherical Carbonaceous Particles (SCP) of industrial origin was also detected. A similar trend in SCP concentration was found in other five neighbouring mountain lakes (Lami et al. 1994), indicating that their deposition was a regional phenomenon related to the long range transport of air pollutants, rather than the effect a local source. The SCP profile follows with a good temporal agreement the temporal trend of the production of electric power in Italy. It is worthwhile to note that most of the industrial and power plants in Italy are located in the northern part of the country, close to the Alps.

Comparing the profile of $\mathrm{pH}$ and of SCP, we can infer that the use of fossil fuel for industrial purposes in Northern Italy lead to a widespread emission of atmospheric pollutants, which reached the Alps in the form of acid deposition, carrying also SCPs and other pollutants, such as heavy metals. LPS responded to the increasing deposition of acidifying compounds with a decrease in $\mathrm{pH}$ and alkalinity, with a time lag which can be roughly estimated in one or two decades.

During these studies, the comparison between inferred-pH profile along sediment cores and long-trend series of meteorological data singled out a relationship between lake chemistry and air temperature in previous centuries (Guilizzoni et al. 1993). Before the onset of lake acidification, slightly higher $\mathrm{pH}$ values were inferred for warmer periods and lower $\mathrm{pH}$ for the colder ones. The relationship, previously described by Psenner and Schmidt (1992), puts in evidence the confounding 
factor represented by climate change in the evaluation of lake acidification and recover, and the importance of considering climate-driven change in the modelling of the acidification of high mountain lakes in the Alps (Rogora 2004, this issue; Camarero et al. 2004, this issue).

\section{CONCLUSIONS}

The studies on the Paione lakes clearly showed that high mountain lakes are good sites for the study of the evolution and the effects of the long range transport of atmospheric pollutants from the industrialized lowland to the mountain regions. Systematic monitoring started in the 1980s, when the emission of acidifying compounds into the atmosphere reached its maximum. Palaeolimnological studies showed the acidification of LPS and how the decreasing $\mathrm{pH}$ affected lake biota. In the following twenty years, the application of international agreements led to a substantial reduction of the emissions of sulphur oxides and, consequently of the sulphate deposition reaching the lakes, while nitrate and ammonium deposition are still stable and are assuming a major role in controlling lake acidity. Increasing nitrogen concentration in lake water suggests that catchment soils are close to nitrogen saturation, and may risk further acidification due to decreased nitrate uptake.

In the case of LPS, the most affected by acid deposition, water chemical composition responded positively to the improving quality of atmospheric deposition, with clear increase in both $\mathrm{pH}$ and alkalinity, but the chemical recovery of the lakes became evident only in the last years of the $20^{\text {th }}$ century. On the contrary, signs of improvement of the biota are still absent, apart for an increased proportion of alkaliphylous diatoms in the epipelic community. Comparing the zooplanktonic community with that found in the same lake in the 1940s, the acid sensitive copepod Arctodiaptomus alpinus has not yet reappeared. In the case of LPI, the effects of acid deposition and climate change were not so evident, while the major anthropogenic disturbance was represented by fish overstocking. However, the improvement in lake $\mathrm{pH}$ has led to the appearance of some acid sensitive species in the benthos of LPI outlet.

Long term monitoring showed the importance of the meteorological features, like temperature and droughts, together with deposition of alkaline dust, in controlling lake chemistry, highlighting the confounding effect of climate change on the pattern of lake recovery from acidification.

Finally, the Paione lakes were found to be very sensitive sites for studying the effects of changes in the Alpine chemical and physical climate. Further monitoring is worthwhile to evaluate the direction and extent of the future changes, and to verify the effects of the increasing load of nitrogen and of other pollutants, like Persistent Organic Pollutants (POPs) and heavy metals.

\section{ACKNOWLEDGMENTS}

The research activity summarized in this paper was partially funded by the European Union, through the following projects: "Quantification of the susceptibility of Alpine lakes to acidification" (contract No. EV4V0114), "AL:PE, Acidification of mountain Lakes: Palaeolimnology and Ecology" (contract No. STEP-CT900079-(SMA) and EV5V-CT92-0205), "MOLAR: MOuntain LAkes Research" (contract No. ENV4-CT950007) and "EMERGE: European Mountain lakes Ecosystems: Regionalisation, diaGnostic and socio-economic Evaluation" (contract No. EVK1-CT-19990032). We also acknowledge all the unquoted colleagues, students and friends that shared with us in the last twenty years the paths and the ski tracks leading to the Paione lakes.

\section{REFERENCES}

Agustí-Panareda, A., R. Thompson \& D. Livingstone. 2000. Reconstructing temperature variations at high elevation sites in Europe during the instrumental period. Verh. int. Ver. Limnol., 27: 479-483.

A.N.P.A. 1999. Emissioni in atmosfera e qualità dell'aria in Italia. Serie Stato dell'Ambiente, 6: 116 pp.

Bertoni, R., C. Callieri \& G. Corno. 2002. The mixotrophic flagellates as a key organisms from DOC to Daphnia in an oligotrophic alpine lake. Verh. int. Ver. Limnol., 28: 392-395.

Bertrand, H. 1954. Encyclopédie entomologique. Les insects aquatiques d'Europe. Vol I e II. Paul Lechevalier, Paris, 356 pp (Vol I), 347 pp (Vol II).

Boggero, A. \& A.M. Nocentini. 1994. Macrozoobentos di un lago alpino d'alta quota (Lago di Paione Superiore, Val Bognanco). Atti X Congr. A.I.O.L. Alassio, 4-6 Novembre 1992: 177-187.

Bradford, D.F., S.C. Cooper, T.M. Jenkins, K. Kratz, O. Sarnelle \& A.D. Brown 1998. Influences of natural acidity and introduced fish on faunal assemblages in California alpine lakes. Can. J. Fish. Aquat. Sci., 55: 2478-2491.

Brezonik, P.L., L. Crisman, \& R.L. Schulze. 1984. Planktonic communities in Florida softwater lakes of varying $\mathrm{pH}$. Can. J. Fish. Aquat. Sci., 41: 46-56.

Callieri, C., A. Pugnetti \& M. Manca. 1999. Carbon partitioning in the food web of a high mountain lake: from bacteria to zooplankton. J. Limnol., 58: 144-151.

Camarero, L., R.F. Wright, J. Catalan \& M. Ventura. 2004. Application of MAGIC to Lake Redó (Central Pyrenees): an assessment of the effects of possible climate driven changes in atmospheric precipitation, base cation deposition, and weathering rates on lake water chemistry. $J$. Limnol., 63(1): 123-132.

Cammarano, P. \& M. Manca. 1997. Studies on zooplankton in two acidified high mountain lakes in the Alps. Hydrobiologia, 356: 9-109.

Confer, J.L., G.L. Howick, M.H. Corzette, S.L. Kramer, S. Fitzgibbon, \& R. Landesberg, 1978. Visual predation by planktivores. Oikos, 31: 27-37.

Fjellheim, A., G.G. Raddum \& O.A. Schnell. 2000a. Protocol for the sampling of contemporary invertebrates. Protocol 06. In: Wathne, B. \& S. Patrick (Eds), Manual of unified methods used throughout the EMERGE project. Manual of the EU EMERGE project: 3 pp.

Fjellheim, A., A. Boggero, A.M. Nocentini, M. Rieradevall, G.G. Raddum \& O. Schnell. 2000b. Distribution of benthic invertebrates in relation to environmental factors. A study of European remote alpine lake ecosystems. Verh. int. Ver. Limnol., 26: 484-488. 
Fott J., M. Prazáková, E. Stuchlík \& Z. Stuchlícová. 1994. Acidification of lakes in Šmava (Bohemia) and in the High Tatra Mountains (Slovakia). Hydrobiologia, 274: 37-47.

Frost, S., A. Huni, \& W.E. Kershaw. 1971. Evaluation of a kicking technique for sampling stream bottom fauna. Can. J. Zool., 49: 167-173.

Giussani, G., R. de Bernardi, R. Mosello, I. Origgi \& T. Ruffoni. 1986. Indagine limnologica sui laghi alpini d'alta quota. Documenta Ist. ital. Idrobiol. 9: 415pp.

Guilizzoni, P., A. Lami \& A. Marchetto. 1993. The sediment core analyses in high altitude lakes of Central Alps: Comparison of three inferring-pH techniques and effect of temperature on lake acidification. Mem. Ist. ital. Idrobiol., 52: 387-400.

Guilizzoni, P., A. Marchetto, A. Lami, N.G. Cameron, P.G Appleby, N.L. Rose, Ø. A. Schnell, C.A. Belis, A. Giorgis \& L. Guzzi. 1996. The environmental history of a mountain lake (Lago Paione Superiore, Central Alps, Italy) for the last c. 100 years: a multidisciplinary, paleolimnological study. J. Paleolimnol., 15: 245-264.

Hall, D.J. 1964. An experimental approach to the dynamics of a natural population of Daphnia galeata mendotae. Ecology, 45: 94-112.

Hieber, M., C.T. Robinson, U. Uehlinger \& J.V. Ward. 2002. Are alpine lake outlets less harsh than other alpine streams? Arch. Hydrobiol., 154: 199-223.

IPCC. 2001. Climate Change 2001: The Scientific Basis. Contribution of Working Group I to the Third Assessment Report of the Intergovernmental Panel on Climate Change (IPCC). J. T. Houghton, Y. Ding, D.J. Griggs, M. Noguer, P. J. van der Linden and D. Xiaosu (Eds), Cambridge University Press, UK: 944 pp.

Isaksson, A. 1998. Phagotrophic phytoflagellates in lakes - a literature review. Arch. Hydrobiol. Spec. Issues Advanc. Limnol., 51: 63-90.

Kernan, M. \& J. Catalan. 2003. A typology for European mountain lakes. Proceedings of the Symposium "How to assess and monitor ecological quality in freshwaters", 2325 October 2003, Helsinki, Finland. Tema Nord 2003:547, Nordic Council of Ministers, Copenhagen: $214 \mathrm{pp.}$

Lami, A., M. Maugeri, R. Mosello \& R. Puricelli. 2002. La serie ultrasecolare di misure dell’Osservatorio Meteorologico "A. Rosmini" di Domodossola. II. La temperatura dell'aria. Oscellana, 32: 13-27.

Lami, A., A. Marchetto, P. Guilizzoni, A. Giorgis \& J. Masaferro. 1994. Paleolimnological records of carotenoids and carbonaceous particles in sediments of some lakes in Southern Alps. Hydrobiologia, 274: 57-64.

Locke, A. \& W.G. Sprules, 1994. Effects of lake acidification and recovery on the stability of zooplankton food webs. Ecology, 75: 498-506.

Manca, M. \& M. Armiraglio. 2002. Zooplankton of 15 lakes in the Southern central Alps: comparison of recent and past (pre-1850 AD) communities. J. Limnol., 61: 225-231.

Maugeri, M., A. Lami, R. Mosello \& R. Puricelli. 2002. La serie ultrasecolare di misure dell’Osservatorio Meteorologico "A. Rosmini" di Domodossola. III. Le precipitazioni. Oscellana, 32: 79-97.

Mosello, R. 1984 . Hydrochemistry of high altitude alpine lakes. Schweiz Z. Hydrol., 46: 86-99.

Mosello, R., A. Marchetto, A. Boggero, M.C. Brizzio, G.A. Tartari \& M. Rogora. 1999. Pluriannual evolution of the hydrochemistry of two alpine lakes (Lake Paione Inferiore and Lake Paione Superiore, Ossola Valley) in relation to atmospheric loads. J. Limnol., 58: 43-49.

Mosello, R., A. Lami, A. Marchetto, M. Rogora, B. Wathne, L. Lien, J. Catalan, L. Camarero, M. Ventura, R. Psenner, K. Koinig, H. Thies, S. Sommaruga-Wögrath, U. Nickus, D. Tait, B. Thaler, A. Barbieri \& R. Harriman. 2002 Trends in the water chemistry of high altitude lakes in Europe. Water Air Soil Pollut.: Focus, 2: 75-89.
O’Brien, W.J. 1987. Planktivory by freshwater fish: thrust and parry in the pelagia. In: C. Kerfoot \& A. Sih (Eds), Predation. Direct and Indirect Impact on Aquatic Communities. Hanover and London. University Press of New England: 3-16.

Patrick, S., R.W. Battarbee, B. Wathne \& R. Psenner. 1998 Measuring and modelling the dynamic response of remote mountain lake ecosystems to environmental change: an introduction to the MOLAR project. Hydrology, Water Resources and Ecology in Headwater (Proc. of the Headwater Conference, Meran, Italy, April 1998), IAHS Publ. 248: 403-410.

Pechlaner, R. 1971. Factors that control the production rate and biomass of phytoplankton in high mountain lakes. Mitt. Internat. Verein. Limnol., 19: 123-145.

Pinder, L.C.V. 1982. The larvae of Chironomidae (Diptera) of the Holarctic region - Introduction. In: Wiederholm, T. (Ed.), Chironomidae of the Holarctic region. Keys and diagnosis. Part 1-Larvae. Ent. Scand., suppl. 19: 7-10.

Psenner, R. 1999. Living in a dusty world: airborne dust as a key factor for alpine lakes. Water Air Soil Pollut., 112: 217-227.

Psenner, R. \& R. Schmidt. 1992. Climate-driven pH control of remote mountain lakes and effects on acid deposition. Nature, 356: 781-783.

Pugnetti, A. \& R. Bettinetti. 1995. The phytoplankton communities of two acid sensitive alpine lakes (lakes Paione, Central Alps, Italy). Mem. Ist. ital. Idrobiol., 53: 39-50.

Pugnetti, A. \& R. Bettinetti. 1999. Biomass and species structure of the phytoplankton of an high mountain lake (Lake Paione Superiore, Central Alps, Italy). J. Limnol., 58: 127-130.

Pugnetti, A., M. Manca, A.M. Nocentini, A. Boggero, R. Bettinetti, M. Bonardi \& P. Cammarano. 1993. Ecological aspects of two Alpine lakes (Lakes Paione, Italy). Proc. 5th Int. Conf., Conservation and management of lakes: strategies for lake ecosystems beyond 2000. Stresa, 17-21 May 1993: 440-443.

Rendberg, I. 1990. A procedure for preparing large sets of diatom slides from sediment cores. J. Paleolimnol., 4: 8790.

Rhode, W. 1955. Can plankton production proceed during winter darkness in subarctic lakes? Mitt. Internat. Verein. Limnol., 12: 117-122.

Rogora, M. 2004. Acidification and recovery at mountain lakes in Central Alps assessed by the MAGIC model. $J$. Limnol., 63(1): 133-142.

Rogora, M., A. Marchetto \& R. Mosello. 2001. Trends in the chemistry of atmospheric deposition and surface waters in the Lago Maggiore watershed. Hydrol. Earth System Sci., 5: 379-390.

Rogora, M., R. Mosello \& S. Arisci. 2003. The effect of climate warming on the hydrochemistry of alpine lakes. Water Air Soil Pollut., 148: 347-361.

Rogora, M., R. Mosello \& A. Marchetto. (2004). Long-term trends in the chemistry of atmospheric deposition in NW Italy: the role of increasing Saharan dust deposition. Tellus $B$ : (in press).

Sandgren, C.D. \& J.V. Robinson. 1984. A stratified sampling approach to compensating for non-random sedimentation of phytoplankton cells in inverted microscope settling chambers. Br. Phycol. J., 19: 67-72.

Schmidt, R., A. Klaus, J. Fott, Z. Rehaova, V. Straskrábová, \& J. Vesely. 1992. Acidification of Bohemian Lakes. Recent trends and historical development. Im Auftrag des Bundeministerium für Wissenschaft und Foschung und der Österreichen Akademie der Wissenschaften: 58 pp.

Sommaruga-Wögrath, S., K.A. Koining, R. Schmidt, R. Sommaruga, R. Tessadri \& R. Psenner. 1997. Temperature effects on the acidity of remote alpine lakes. Nature, 387 : 64-67. 
Storey, A.W., D.H.D. Edward \& P. Gazey. 1991. Surber and kick sampling: a comparison for the assessment of macroinvertebrate community structure in streams of south- western Australia. Hydrobiologia, 211: 111-121.

Tait, D. \& B. Thaler. 2000. Atmospheric deposition and lake chemistry trends at a high mountain site in the Eastern Alps. J. Limnol., 59: 61-71.

Tartari, G.A. \& R. Mosello. 1997. Metodologie analitiche e controlli di qualità nel laboratorio chimico dell'Istituto Italiano di Idrobiologia del Consiglio Nazionale delle Ricerche. Documenta Ist. ital. Idrobiol., 60: 160 pp.

The MOLAR Water Chemistry Group. 1999. The MOLAR Project: atmospheric deposition and lake water chemistry. J. Limnol., 58: 88-106.

Tonolli, V. 1949. Gli alti laghi della Val Bognanco. Parte II. Mem. Ist. ital. Idrobiol., 5: 39-93.

Tonolli, V. \& L. Tonolli. 1951. Osservazioni sulla biologia ed ecologia di 170 popolamenti zooplanctonici di laghi alpini d'alta quota. Mem. Ist. ital. Idrobiol., 6: 53-136.

Tortonese, T. 1970. Osteichtyes. Pesci ossei. Calderini editore. Bologna: 565 pp.
Vyhnàlek, V., J. Fott \& J. Kopàcek. 1994. Chlorophyll phosphorus relationship in acidified lakes of the High Tatra Mountains (Slovakia). Hydrobiologia, 274: 171-177.

Wathne, B.M., S.T. Patrick, D. Monteith \& H. Barth. 1995. AL:PE - Acidification of mountain lakes: palaelimnology and ecology. AL:PE 1 report for the period April $1991-$ April 1993. European Commission, Ecosystem Research Report 9, Luxembourg: 296 pp.

Wathne, B.M., S. Patrick \& N.G. Cameron. 1997. AL:PE Project part 2-Remote mountain lakes as indicators of air pollution and climate change. European commission, CEC-Environment, Bruxelles/ Norwegian Institute of Water Research. NIVA report 3638-97, Oslo.

Watras, C.J. \& T.M. Frost. 1989. Little Rock Lake (Wisconsin): perspectives on an experimental ecosystem approach to seepage lake acidification. Arch. Environ. Contam. Toxicol., 18: 157-165.

Wright, D.I. \& W.J. O'Brien. 1982. Differential location Chaoborus larvae and Daphnia by fish: The importance of motion and visible size. Am. Midlands Naturalist, 108: 6873. 